\title{
CONTRACTILE EFFECTS OF ARGININE ANALOGUES ON HUMAN INTERNAL THORACIC AND RADIAL ARTERIES
}

Gloria Segarra, BSc ${ }^{\mathrm{a}}$

Pascual Medina, $\mathrm{PhD}^{\mathrm{a}}$

José María Vila, $\mathrm{PhD}^{\mathrm{a}}$

Juan Bautista Martínez-León, MD

Rosa María Ballester, BSc ${ }^{\mathrm{a}}$

Paloma Lluch, MD, ${ }^{\mathrm{c}}$

Salvador Lluch, $\mathrm{MD}^{\mathrm{a}}$
Objectives: Plasma levels of endogenous guanidino-substituted analogues of L-arginine are increased in various pathologic conditions. In the present study we determined the effects of some of these compounds on basal and stimulated release of nitric oxide in human internal thoracic and radial arteries.

Methods: Rings of human internal thoracic and radial arteries were obtained from 16 multiorgan donors. The rings were suspended in organ baths for isometric recording of tension.

Results: $\mathrm{N}^{\mathrm{G}}$-monomethyl L-arginine $\left(10^{-6}\right.$ to $\left.10^{-3} \mathrm{~mol} / \mathrm{L}\right)$ and $\mathrm{N}^{\mathrm{G}}, \mathrm{N}^{\mathrm{G}}$ dimethyl L-arginine $\left(10^{-6}\right.$ to $\left.10^{-3} \mathrm{~mol} / \mathrm{L}\right)$ caused concentration- and endothelium-dependent contractions. Maximal force of contractions for $\mathrm{N}^{\mathrm{G}}$ monomethyl L-arginine and $\mathrm{N}^{\mathrm{G}}, \mathrm{N}^{\mathrm{G}}$-dimethyl $\mathrm{L}$-arginine in the internal thoracic artery were $18.0 \% \pm 4.3 \%$ and $17.8 \% \pm 3.8 \%$, respectively, of the contraction to $100 \mathrm{mmol} / \mathrm{L} \mathrm{KCl}$, and those found in the radial artery were $9.6 \% \pm 2.5 \%$ and $9.1 \% \pm 2.4 \%$, respectively. Aminoguanidine $\left(10^{-5}\right.$ to $3 \times$ $\left.10^{-3} \mathrm{~mol} / \mathrm{L}\right)$ and methylguanidine $\left(10^{-5}\right.$ to $\left.3 \times 10^{-3} \mathrm{~mol} / \mathrm{L}\right)$ produced endothelium-independent contractions. L-Arginine $\left(10^{-3} \mathrm{~mol} / \mathrm{L}\right)$ prevented the contractions by $\mathrm{N}^{\mathrm{G}}$-monomethyl L-arginine and $\mathrm{N}^{\mathrm{G}}, \mathrm{N}^{\mathrm{G}}$-dimethyl L-arginine but did not change contractions induced by aminoguanidine and methylguanidine. $\mathrm{N}^{\mathrm{G}}$-monomethyl L-arginine and $\mathrm{N}^{\mathrm{G}}, \mathrm{N}^{\mathrm{G}}$-dimethyl L-arginine inhibited, in a concentration-dependent manner, the endotheliumdependent relaxation to acetylcholine in the internal thoracic artery and had little attenuating effect in the radial artery; aminoguanidine and methylguanidine were without effect.

Conclusions: The results suggest that the contractions induced by $\mathrm{N}^{\mathrm{G}}$ monomethyl $\mathrm{L}$-arginine and $\mathrm{N}^{\mathrm{G}}, \mathrm{N}^{\mathrm{G}}$-dimethyl $\mathrm{L}$-arginine are due to inhibition of both basal and stimulated nitric oxide production, whereas aminoguanidine and methylguanidine do not affect the synthesis of nitric oxide. An increase in the plasma concentration of $\mathrm{N}^{\mathrm{G}}$-monomethyl $\mathrm{L}$-arginine and $\mathrm{N}^{\mathrm{G}}, \mathrm{N}^{\mathrm{G}}$-dimethyl L-arginine is likely to represent a risk factor for abnormal vasomotor tone in conduit arteries used as coronary grafts. ( $\mathrm{J}$ Thorac Cardiovasc Surg 2000;120:729-36)
From the Departments of Physiology, ${ }^{\mathrm{a}}$ Surgery, ${ }^{\mathrm{b}}$ and Medicine ${ }^{\mathrm{c}}$ University of Valencia School of Medicine, Valencia, Spain.

Supported by the Comisión Interministerial de Ciencia y Tecnología, Ministerio de Sanidad and Generalitat Valenciana. G.S. was the recipient of a Fellowship of the Instituto de Salud Carlos III (99/9016).

Received for publication Feb 23, 2000; revisions requested April 25, 2000; revisions received June 1, 2000; accepted for publication June 14, 2000.

Address for reprints: S. Lluch, MD, Departamento de Fisiología, Facultad de Medicina y Odontología, Blasco Ibáñez, 17, 46010 Valencia, Spain (E-mail: medinap@post.uv.es).

Copyright (C) 2000 by The American Association for Thoracic Surgery

0022-5223/2000 $\$ 12.00+0 \quad \mathbf{1 2 / 1 / 1 0 9 5 3 7}$

doi: $10.1067 / \mathrm{mtc} .2000 .109537$
$\Lambda$ number of guanidino-substituted analogues of $\mathrm{L}-$ A arginine are synthesized endogenously and can act as inhibitors of nitric oxide synthase, the enzyme responsible for the formation of nitric oxide (NO) from the amino acid precursor L-arginine. ${ }^{1,2}$ Of particular interest are $\mathrm{N}^{\mathrm{G}}, \mathrm{N}^{\mathrm{G}}$-dimethyl L-arginine (ADMA) and $\mathrm{N}^{\mathrm{G}}$-monomethyl L-arginine (L-NMMA). The plasma levels of both of these L-arginine analogues are significantly increased in various pathologic conditions, including end-stage renal failure ${ }^{3}$ congestive heart failure,${ }^{4}$ pre-eclampsia, ${ }^{5}$ peripheral arterial occlusive disease, ${ }^{6}$ and hypertension. ${ }^{7,8}$ Furthermore, these compounds produced dose-dependent inhibition of nitrite 
production by macrophages (J774 cells) and reversed endothelium-dependent relaxation in human saphenous veins $^{9}$ and human and rat cerebral arteries. ${ }^{10,11}$

Whether these compounds affect the responsiveness of arterial grafts used for coronary bypass surgery, such as the internal thoracic and radial arteries, remains to be determined. An increase in plasma concentrations of these compounds is likely to induce a decreased synthesis of endothelial NO and a diminished response to endothelium-mediated relaxation. Both circumstances may explain, at least in part, the differences in longterm survival and reactivity to pharmacologic agents between these arteries. ${ }^{12}$ The purpose of the present work was to evaluate the potency and selectivity of ADMA, L-NMMA, methylguanidine (MG), and aminoguanidine (AG) on endothelium-dependent and endothelium-independent relaxation of human internal thoracic and radial arteries. Because continuous release of NO from endothelial cells is an important determinant of the underlying smooth muscle tone in animals and human subjects, ${ }^{13-17}$ we also examined the ability of these compounds to inhibit basal NO release by measuring the effect on vascular tone.

\section{Methods}

Internal thoracic and radial arteries were obtained from 16 multiorgan donors during procurement of organs for transplantation (10 men and 6 women; age range, 17-60 years). The study was approved by the ethical committee of our institution. The vessels were immediately placed in cold $\left(4^{\circ} \mathrm{C}\right)$ modified Krebs solution (for composition see below) aerated with $95 \%$ oxygen and $5 \%$ carbon dioxide until use (within 8 hours of collection).

The vessels were cleaned of adherent connective tissue and cut into rings ( $3 \mathrm{~mm}$ in length) under a dissecting microscope (Leica Geosystems, Heerbrugg, Switzerland). In approximately $30 \%$ of the artery rings, the endothelium was removed mechanically by inserting a roughened stainless-steel wire into the lumen and gently rolling the vessel ring on wet filter paper. Each ring was suspended between two stainless-steel L-shaped pins in 4-mL organ baths containing modified Krebs solution of the following composition: $\mathrm{NaCl}, 115$ $\mathrm{mmol} / \mathrm{L} ; \mathrm{KCl}, 4.6 \mathrm{mmol} / \mathrm{L} ; \mathrm{MgSO}_{4}, 1.2 \mathrm{mmol} / \mathrm{L} ; \mathrm{CaCl}_{2}, 2.5$ $\mathrm{mmol} / \mathrm{L} ; \mathrm{NaHCO}_{3}, 25 \mathrm{mmol} / \mathrm{L} ; \mathrm{KH}_{2} \mathrm{PO}_{4}, 1.2 \mathrm{mmol} / \mathrm{L}$; glucose, $11.1 \mathrm{mmol} / \mathrm{L}$; and disodium ethylenediamine tetraacetic acid, $0.01 \mathrm{mmol} / \mathrm{L}$. The solution was equilibrated with $95 \%$ oxygen and $5 \%$ carbon dioxide to give a $\mathrm{pH}$ of 7.3 to 7.4 . Temperature was held at $37^{\circ} \mathrm{C}$. One pin was fixed to the organ bath wall, and the other was connected to a strain gauge (model FT03; Grass Instrument Division of Astro-Med, Inc, West Warwick, RI). Changes in isometric force were recorded on a Macintosh computer (Apple Computer, Cupertino, Calif) by use of Chart version 3.4/s software and a MacLab/8e data acquisition system (ADInstruments,
Mountain View, Calif). To establish the resting tension for maximal force development, we performed a series of preliminary experiments on rings of similar length and outer diameter, which were exposed repeatedly to $100 \mathrm{mmol} / \mathrm{L}$ $\mathrm{KCl}$. Basal tension was increased gradually until contractions were maximal. The optimal resting tension was $3 g$ for the internal thoracic artery and $4 g$ for the radial artery. The rings were allowed to attain a steady level of tension during a 2- to 3-hour accommodation period before testing. Functional integrity of the endothelium was confirmed routinely by the presence of relaxation induced by acetylcholine $\left(10^{-8}\right.$ to $10^{-7}$ $\mathrm{mol} / \mathrm{L}$ ) during contraction obtained with norepinephrine $\left(10^{-7}\right.$ to $\left.3 \times 10^{-7} \mathrm{~mol} / \mathrm{L}\right)$.

All experiments were performed in the presence of $10^{-5}$ $\mathrm{mol} / \mathrm{L}$ indomethacin (INN: indometacin) to inhibit prostanoid synthesis.

To study contraction, concentration-response curves to LNMMA $\left(10^{-6}\right.$ to $\left.10^{-3} \mathrm{~mol} / \mathrm{L}\right)$, ADMA $\left(10^{-6}\right.$ to $\left.10^{-3} \mathrm{~mol} / \mathrm{L}\right)$, AG $\left(10^{-5}\right.$ to $\left.3 \times 10^{-3} \mathrm{~mol} / \mathrm{L}\right)$, and $\mathrm{MG}\left(10^{-5}\right.$ to $\left.3 \times 10^{-3} \mathrm{~mol} / \mathrm{L}\right)$ were determined in artery rings under resting tension. In another series of experiments concentration-response curves were determined after evoking tone (approximately $500 \mathrm{mg}$ for the internal thoracic artery and $700 \mathrm{mg}$ for the radial artery) with norepinephrine. In a separate group of experiments, the contractile effects of guanidino compounds were studied in the presence of L-arginine $\left(10^{-3} \mathrm{~mol} / \mathrm{L}\right)$.

To study the effects of guanidino compounds on relaxation, vessels were precontracted with norepinephrine (1.5-2 $\mathrm{g}$ for the internal thoracic artery and 3-4 g for the radial artery), and cumulative relaxation curves to either acetylcholine $\left(10^{-10}\right.$ to $\left.10^{-5} \mathrm{~mol} / \mathrm{L}\right)$ or sodium nitroprusside $\left(10^{-10}\right.$ to $10^{-7}$ $\mathrm{mol} / \mathrm{L}$ ) were constructed in the absence and presence of $\mathrm{L}$ NMMA, ADMA, AG, or MG (all at $10^{-5}$ to $10^{-3} \mathrm{~mol} / \mathrm{L}$ ). In a separate series of experiments, the effects of guanidino compounds on acetylcholine-induced relaxation were studied in the presence of L-arginine $\left(10^{-3} \mathrm{~mol} / \mathrm{L}\right)$.

Drugs. The following drugs were used: acetylcholine chloride, norepinephrine hydrochloride, $\mathrm{N}^{\mathrm{G}}$-monomethyl L-arginine acetate, $\mathrm{N}^{\mathrm{G}}, \mathrm{N}^{\mathrm{G}}$-dimethylarginine hydrochloride, aminoguanidine hydrochloride, methylguanidine hydrochloride, L-arginine hydrochloride, indomethacin, and sodium nitroprusside dihydrate (Sigma Chemical Co, St Louis, Mo). Drugs were prepared and diluted in distilled water, except for indomethacin, which was dissolved in absolute ethanol and sodium bicarbonate solution ( $150 \mathrm{mmol} / \mathrm{L})$, and readjusted to $\mathrm{pH} 7.4$ with $\mathrm{HCl}$ before use. Stock solutions of the drugs were freshly prepared every day.

Data analysis. All values are expressed as means \pm SEM The contractile effects of L-NMMA, ADMA, AG, and MG were determined after evoking submaximal tone with norepinephrine $\left(3 \times 10^{-8}\right.$ to $\left.10^{-7} \mathrm{~mol} / \mathrm{L}\right)$. The change from the preexisting tension was expressed as a percentage of the response to $\mathrm{KCl}(100$ $\mathrm{mmol} / \mathrm{L}$ ). Relaxation was expressed as a percentage of the norepinephrine-induced contraction $\left(3 \times 10^{-7} \mathrm{~mol} / \mathrm{L}\right)$.

Concentrations of agonist producing half-maximal contraction or relaxation $\left(\mathrm{EC}_{50}\right)$ were determined from individual concentration-response curves by using nonlinear regression 

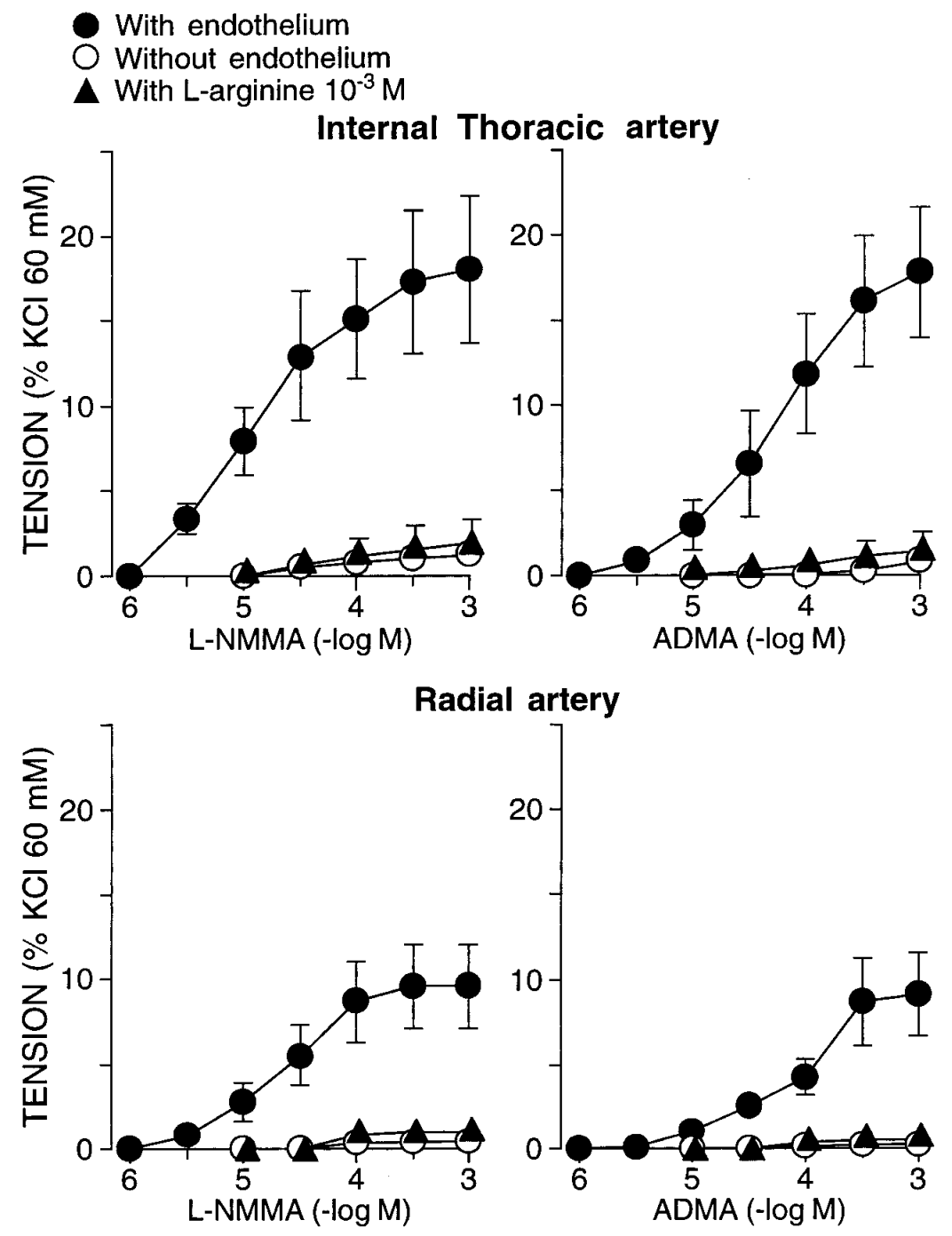

Fig 1. Contractions induced by L-NMMA $(n=6)$ and ADMA $(n=6)$ on rings of human internal thoracic and radial arteries with and without endothelium and in rings with endothelium treated with $\mathrm{L}$-arginine $\left(10^{-3} \mathrm{~mol} / \mathrm{L}, \mathrm{n}=4\right)$. Contractions were determined after evoking submaximal tone with norepinephrine, and the change from the preexisting tone is expressed as a percentage of response to $100 \mathrm{mmol} / \mathrm{L} \mathrm{KCl}$. Values are means $\pm \mathrm{SEM}$.

analysis, and from these values, the geometric means were calculated. The number of rings taken from each subject varied from 8 to 12. The responses obtained in each subject were averaged to yield a single value. Therefore, all (n) values are presented as the number of subjects. Differences between agonist- and antagonist-treated groups were assessed by 2 way analysis of variance.

\section{Results}

Maximal contractions to $\mathrm{KCl}$ and norepinephrine were greater in the radial artery $(9835 \pm 364$ and $11763 \pm 1466 \mathrm{mg}$, respectively; $\mathrm{n}=6$ ) than in the internal thoracic artery $(4438 \pm 203$ and $4008 \pm 567$ $\mathrm{mg}$, respectively; $\mathrm{n}=5) . \mathrm{EC}_{50}$ values for norepinephrine were $9.3 \times 10^{-7} \mathrm{~mol} / \mathrm{L}$ in the radial artery and $3.0 \times 10^{-7} \mathrm{~mol} / \mathrm{L}$ in the internal thoracic artery.

Arteries exposed to L-NMMA, ADMA, AG, and MG $\left(10^{-5}\right.$ to $\left.10^{-3} \mathrm{~mol} / \mathrm{L}\right)$ did not show significant changes in resting tension. In the presence of threshold concentrations of norepinephrine, L-NMMA and ADMA $\left(10^{-6}\right.$ to $10^{-3} \mathrm{~mol} / \mathrm{L}$ ) produced concentration-dependent increases in tension in artery rings with endothelium but not in endothelium-denuded rings (Fig 1). The $\mathrm{EC}_{50}$ values for L-NMMA and ADMA in the internal tho- 

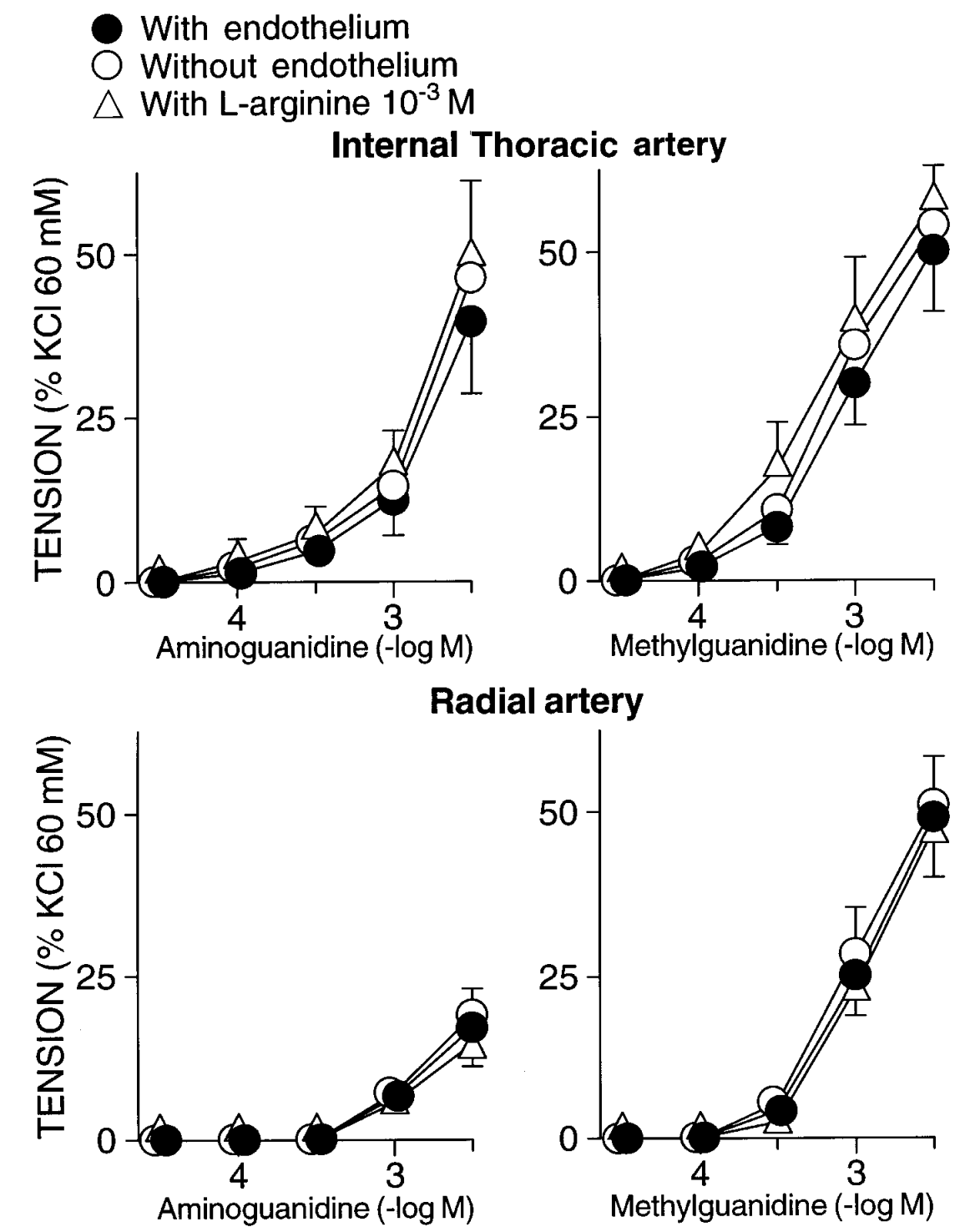

Radial artery

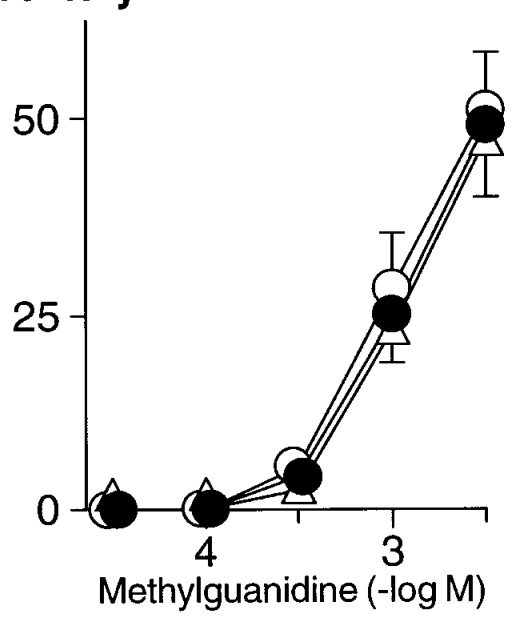

Fig 2. Contractions induced by $\mathrm{AG}(\mathrm{n}=5)$ and $\mathrm{MG}(\mathrm{n}=5)$ on rings of human internal thoracic and radial arteries with and without endothelium and in rings with endothelium treated with $\mathrm{L}$-arginine $\left(10^{-3} \mathrm{~mol} / \mathrm{L}, \mathrm{n}=4\right)$. Values are means \pm SEM.

racic artery were $1.4 \times 10^{-5} \mathrm{~mol} / \mathrm{L}$ and $6.5 \times 10^{-5} \mathrm{~mol} / \mathrm{L}$, respectively $(\mathrm{n}=6)$, and $2.7 \times 10^{-5} \mathrm{~mol} / \mathrm{L}$ and $1.0 \times 10^{-5}$ $\mathrm{mol} / \mathrm{L}$, respectively, in the radial artery $(n=6)$. AG and MG augmented norepinephrine-induced tone at concentrations greater than $10^{-4} \mathrm{~mol} / \mathrm{L}$; this response was endothelium independent (Fig 2). The $\mathrm{EC}_{50}$ values were not determined for $\mathrm{MG}$ and $\mathrm{AG}$ because their curves did not reach a plateau at concentrations up to 3 $\times 10^{-3} \mathrm{~mol} / \mathrm{L}(\mathrm{n}=5$ for each compound). Previous addition of L-arginine $\left(10^{-3} \mathrm{~mol} / \mathrm{L}\right)$ prevented the increase in tension induced by L-NMMA $(\mathrm{n}=4)$ and ADMA (n
$=4 ;$ Fig 1$)$ but did not change contractions induced by $\mathrm{AG}(\mathrm{n}=4)$ and $\mathrm{MG}(\mathrm{n}=4$; Fig 2).

Acetylcholine $\left(10^{-10}\right.$ to $\left.10^{-5} \mathrm{~mol} / \mathrm{L}\right)$ caused endothelium-dependent relaxations $\left(\mathrm{EC}_{50}=1.7 \times 10^{-7} \mathrm{~mol} / \mathrm{L}\right.$ in internal thoracic artery; $\mathrm{EC}_{50}=1.8 \times 10^{-9} \mathrm{~mol} / \mathrm{L}$ in radial artery) in rings contracted with norepinephrine (Fig 3). The relaxation induced by acetylcholine was inhibited in a concentration-dependent manner by LNMMA $\left(10^{-5}\right.$ to $\left.10^{-3} \mathrm{~mol} / \mathrm{L}\right)$ and ADMA $\left(10^{-5}\right.$ to $10^{-3}$ $\mathrm{mol} / \mathrm{L}$; Fig 3). Maximal relaxations of internal thoracic arteries evoked by acetylcholine in the presence of L- 

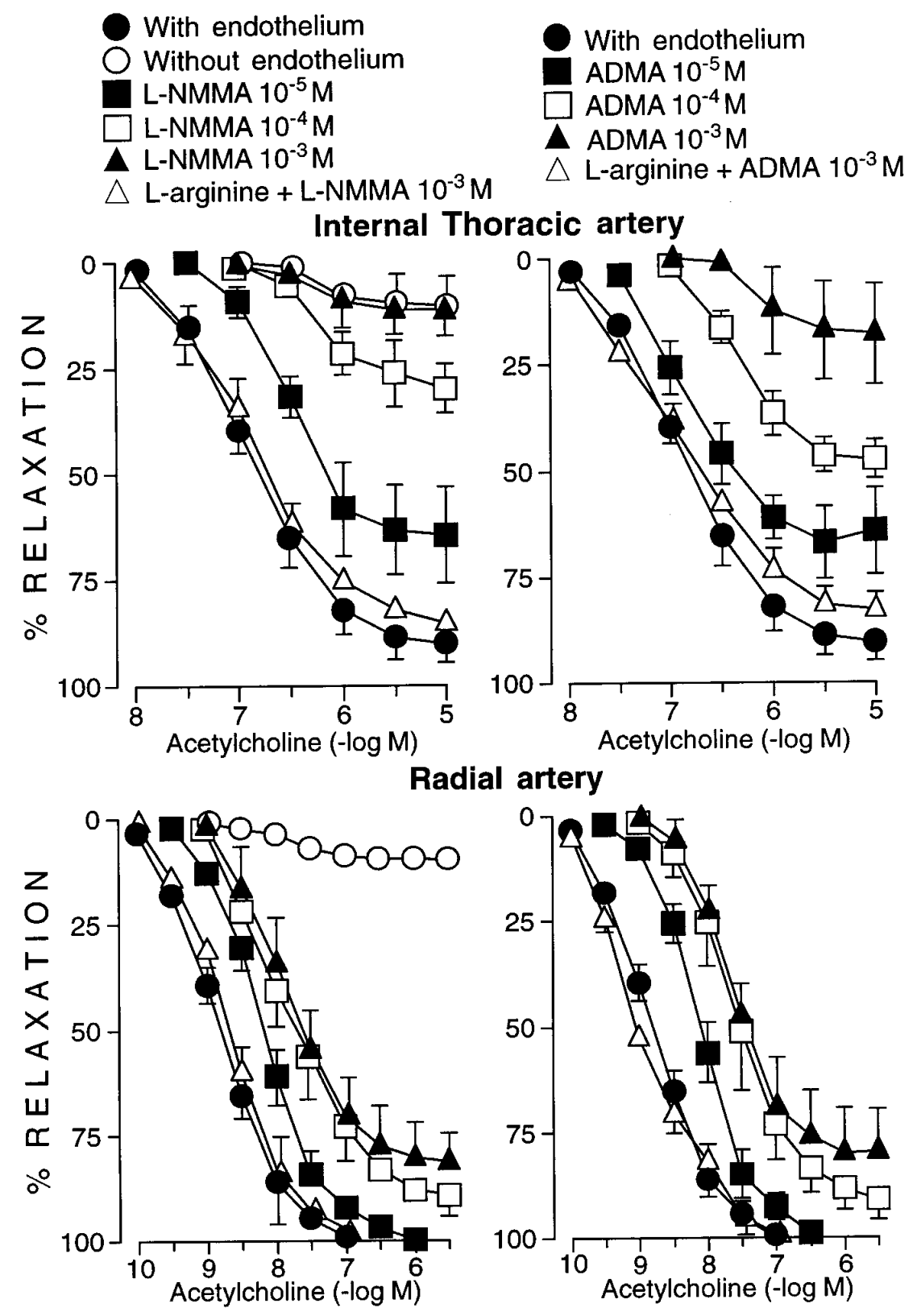

Fig 3. Inhibition by L-NMMA and ADMA of the relaxation of human internal thoracic and radial artery rings induced by acetylcholine. The inhibitory effects of L-NMMA $\left(10^{-3} \mathrm{~mol} / \mathrm{L}, \mathrm{n}=5\right)$ and ADMA $\left(10^{-3} \mathrm{~mol} / \mathrm{L}, \mathrm{n}=5\right)$ were completely prevented in the presence of $10^{-3} \mathrm{~mol} / \mathrm{L} \mathrm{L}$-arginine $(\mathrm{n}=4)$. Relaxation is expressed as a percentage of the contraction in response to $3 \times 10^{-7} \mathrm{~mol} / \mathrm{L}$ norepinephrine. Values are means $\pm \mathrm{SEM}$.

NMMA $\left(10^{-3} \mathrm{~mol} / \mathrm{L}, \mathrm{n}=5\right)$ and ADMA $\left(10^{-3} \mathrm{~mol} / \mathrm{L}\right.$, $\mathrm{n}=5)$ were $10.6 \% \pm 7.0 \%$ and $18.0 \% \pm 11.8 \%$, respectively. However, a sizeable relaxation of the radial arteries to acetylcholine remained in the presence of the highest concentration of L-NMMA or ADMA $(78.5 \% \pm 7.1 \%$ and $79.5 \% \pm 10.0 \%$, respectively;
Fig 3). The inhibitory effects of L-NMMA and ADMA on acetylcholine-induced relaxation were completely prevented by L-arginine $\left(10^{-3} \mathrm{~mol} / \mathrm{L}\right)$ in both arteries. Neither MG $\left(10^{-5}\right.$ to $\left.10^{-3} \mathrm{~mol} / \mathrm{L}, \mathrm{n}=4\right)$ nor AG $\left(10^{-5}\right.$ to $10^{-3} \mathrm{~mol} / \mathrm{L}, \mathrm{n}=4$ ) had any effect on the relaxation induced by acetylcholine (results not shown). 
In endothelium-intact and endothelium-denuded rings, sodium nitroprusside $\left(10^{-10}\right.$ to $\left.10^{-7} \mathrm{~mol} / \mathrm{L}\right)$ induced complete $(100 \%)$ relaxation of precontracted artery rings, with an $\mathrm{EC}_{50}$ of $1.0 \times 10^{-8} \mathrm{~mol} / \mathrm{L}$ for internal thoracic arteries and $5.2 \times 10^{-9} \mathrm{~mol} / \mathrm{L}$ for radial arteries. None of the guanidino compounds $\left(10^{-4}\right.$ $\mathrm{mol} / \mathrm{L}$ ) modified the relaxation curves to sodium nitroprusside ( $n=4$ for each compound; results not shown).

\section{Comment}

The present study was designed to test the influence of various guanidino compounds on vascular tone and NO-dependent vasodilating function in human radial and internal thoracic arteries. The results demonstrate that L-NMMA and ADMA caused concentration-dependent contractions of these arteries. The contractile effects were endothelium dependent and were fully reversed by L-arginine, the substrate for the enzyme for NO synthesis. These findings indicate that L-NMMA and ADMA increase the tone of these vessels by inhibiting the basal release of NO from the endothelium. In addition, the magnitude of the contractile effects suggests that the internal thoracic artery releases more NO under basal conditions than the radial artery. This difference may be of clinical relevance because it is the basal release of NO that modifies the underlying smooth muscle tone. ${ }^{13,14,18}$ The small contraction obtained in the radial artery indicates a small tonic release of NO under basal conditions. This effect is similar to that reported in human subjects at the level of the distal segment of the epicardial coronary artery ${ }^{19}$ and is in contrast with a previous study in human subjects in which L-NMMA decreased radial blood flow but did not affect the diameter of the radial artery. ${ }^{20}$ This discrepancy with our results may be only apparent. Apart from differences between in vivo and in vitro experiments, the concentrations of L-NMMA used in our experiments to induce measurable contractile effects were higher than those used in vivo. ${ }^{20}$ Even at high concentrations $\left(10^{-4}\right.$ mol/L), L-NMMA and ADMA caused only moderate contractions of the radial artery (approximately $8 \%$ of the maximal contraction to $\mathrm{KCl}$ ).

AG and MG produced endothelium-independent contractions and only at high concentrations. L-Arginine did not inhibit these contractions, thus indicating that this effect was not a consequence of inhibition of NO synthesis but rather caused by nonspecific interaction with the vascular smooth muscle. This finding is not unexpected because MG is structurally similar to AG, a compound reported to have a weak inhibitory effect on NO production by the vascular constitutive isoform of NO synthase. 9,21,22 Nonspecific contractions induced by high concentrations of AG and MG have previously been shown in the human saphenous vein. ${ }^{9}$

We also examined the effects of guanidino compounds on the relaxation induced by acetylcholine, which releases endothelium-derived relaxing factor, and by sodium nitroprusside, which releases NO within the smooth muscle cells. We observed that the relaxation induced by acetylcholine was significantly decreased by L-NMMA and ADMA. Because the relaxation to sodium nitroprusside, an endotheliumindependent vasodilator, was not impaired, the absence of relaxation to acetylcholine appears to be a consequence of a decreased synthesis or release of endothelial NO. In contrast, AG and MG had no effect on the relaxation induced by acetylcholine and sodium nitroprusside, thus suggesting that these compounds do not affect the synthesis of endothelial NO.

In agreement with a recent report, ${ }^{23}$ our experiments show that the relaxant response to acetylcholine of the internal thoracic artery was suppressed by L-NMMA or ADMA, whereas in the radial artery the relaxation was reduced but not abolished. This indicates that the relaxation in the internal thoracic artery is wholly dependent on NO release, whereas in the radial artery factors other than NO or prostanoids contribute to acetylcholine-induced relaxation. This is probably the reason for the greater relaxant effects (in terms of $\mathrm{EC}_{50}$ values) of acetylcholine in radial arteries than in internal thoracic arteries. The remaining relaxation after treatment with NO synthase inhibitors observed in our experiments in radial arteries may result from the action of acetylcholine on endothelium-derived hyperpolarizing factor. ${ }^{23-27}$ Although the identity of this non-NO, nonprostanoid, endothelium-derived hyperpolarizing factor remains unknown, several studies have shown that this factor causes hyperpolarization that has been attributed to an increase in $\mathrm{K}^{+}$conductance of the smooth muscle cell membrane. ${ }^{24,28,29}$

Human subjects possess endogenous analogues of Larginine, especially ADMA and L-NMMA, and the enzyme responsible for their synthesis is present in several tissues. ${ }^{30}$ Plasma concentrations of ADMA in healthy human subjects range from 0.5 to $1 \times 10^{-6}$ $\mathrm{mol} / \mathrm{L}, 3,31,32$ and in uremic patients they range from 1.0 to $8.7 \times 10^{-6} \mathrm{~mol} / \mathrm{L} .{ }^{3,31}$ Concentrations of L-NMMA in healthy control subjects appear to be 10 times lower than those of $\mathrm{ADMA}^{3,32}$ but are increased significantly $\left(1.4 \times 10^{-5} \mathrm{~mol} / \mathrm{L}\right)$ in uremic patients. ${ }^{32}$ The increased plasma levels of guanidino compounds associated with a defect in NO formation may be a risk factor to be considered in relation to a recent report ${ }^{33}$ showing that mortality for patients undergoing coronary bypass 
surgery with chronic renal failure is higher than for patients with normal renal function. Circulating concentrations of ADMA are increased in hypercholesterolemic subjects, thus suggesting that ADMA might represent a novel risk factor for endothelial dysfunction. ${ }^{34}$ In fact, it has been shown that despite the absence of angiographic evidence of atherosclerosis, the presence of coronary risk factors may be associated with reduced basal and stimulated release of NO from the human coronary circulation. ${ }^{35}$ The basal release of $\mathrm{NO}$ is a key factor to keep vascular smooth muscle relaxed and to counteract the vasoconstrictor effects of norepinephrine, angiotensin, or endothelin.

Our data indicate that inhibition of NO synthase by accumulation of methylarginines can lead to significant effects on arterial grafts used in coronary bypass surgery. An increase in ADMA and L-NMMA is likely to represent a diminished release or effect of NO, and consequently, a decrease of blood supply to the heart is highly conceivable. Impairment of NO formation in the vessel wall will predispose to vasoconstriction and favor platelet adhesion and aggregation, with the consequent release of vasoconstrictor substances that may exacerbate vasospasm. ${ }^{36}$ These abnormalities may contribute to angina during exertion or emotional stress, two circumstances that increase myocardial work and oxygen demand.

Because the internal thoracic artery releases more NO than the radial artery, both basally and in response to stimulation by acetylcholine, it is assumed that the effects of these arginine analogues will be more prominent in the internal thoracic artery. However, the endothelium-dependent relaxation is more pronounced in the radial artery because of the concomitant release of both NO and non-NO, non-prostanoid hyperpolarizing factor. Our observations also indicate that exogenous L-arginine may compete with the NO synthase inhibitors to restore NO synthesis and endotheliumderived relaxation. It is widely known that L-arginine supplementation enhances the synthesis of endothelium-derived NO and restores endothelial vasodilator function in human subjects. ${ }^{37,38}$ Consistent with this, a recent report has shown that systemic L-arginine infusions improve coronary blood flow and decrease coronary vascular resistance in patients after coronary artery bypass graft (saphenous vein) operations. ${ }^{39}$ Thus, it is possible that the beneficial effects of L-arginine could be due to reversal of the action of the competitive inhibition by ADMA. However, the proof that L-arginine may overcome the decrease in epicardial blood flow induced by high plasma levels of guanidino compounds is still lacking.
In conclusion, the present study supports the hypothesis that accumulation of methylarginines should be considered as a risk factor for endothelial dysfunction and abnormal vasomotor tone in arterial grafts.

\section{REFERENCES}

1. Palmer RMJ, Ashton DS, Moncada S. Vascular endothelial cells synthesize nitric oxide from L-arginine. Nature 1988;333:664-6.

2. Palmer RMJ, Rees DD, Ashton DS, Moncada S. L-Arginine is the physiological precursor for the formation of nitric oxide in endothelium-dependent relaxation. Biochem Biophys Res Commun 1988;153:1251-6.

3. Vallance P, Leone A, Calver A, Collier J, Moncada S. Accumulation of an endogenous inhibitor of nitric oxide synthesis in chronic renal failure. Lancet 1992;339:572-5.

4. Usui M, Matsuoka H, Miyazaki H, Ueda S, Okuda S, Imaizumi T. Increased endogenous nitric oxide synthase inhibitor in patients with congestive heart failure. Life Sci 1998;62:2425-30.

5. Pettersson A, Hedner T, Milsom I. Increased circulating concentrations of asymmetric dimethyl arginine (ADMA), an endogenous inhibitor of nitric oxide synthesis, in preeclampsia. Acta Obstet Gynecol Scand 1998;77:808-13.

6. Böger RH, Bode-Böger SM, Thiele W, Junker W, Alexander K, Frölich JC. Biochemical evidence for impaired nitric oxide synthesis in patients with peripheral arterial occlusive disease. Circulation 1997;95:2068-74.

7. Goonasekera CDA, Rees DD, Woolard P, Frend A, Shah V, Dillon MJ. Nitric oxide synthase inhibitors and hypertension in children and adolescents. J Hypertens 1997;15:901-9.

8. Fujiwara N, Osanai T, Kamada T, Katoh T, Takahashi K, Okumura K. Study on the relationship between plasma nitrite and nitrate level and salt sensitive in human hypertension. Circulation 2000;101:856-61.

9. MacAllister RJ, Whitley GSJ, Vallance P. Effects of guanidino and uremic compounds on nitric oxide pathways. Kidney Int 1994;45:737-42.

10. Segarra G, Medina P, Ballester R, Lluch P, Aldasoro M, Vila JM, et al. Effects of some guanidino compounds on human cerebral arteries. Stroke 1999;30:2206-11.

11. Faraci FM, Brian JE, Heistad DD. Response of cerebral blood vessels to an endogenous inhibitor of nitric oxide synthase. Am J Physiol 1995;271:H1522-7.

12. Rosenfeldt FL, He G, Buxton BF, Angus JA. Pharmacology of coronary artery bypass grafts. Ann Thorac Surg 1999;67:878-88.

13. Rees DD, Palmer RMJ, Moncada S. Role of endothelium-derived nitric oxide in the regulation of blood pressure. Proc Natl Acad Sci U S A 1989;86:3375-8.

14. Vallance P, Collier J, Moncada S. Effects of endothelium-derived nitric oxide on peripheral arteriolar tone in man. Lancet 1989;2:997-1000.

15. Aisaka K, Gross S, Griffith OW, Levi R. $\mathrm{N}^{\mathrm{G}}$-methylarginine, an inhibitor of endothelium-derived nitric oxide synthesis, is a potent pressor agent in the guinea pig: Does nitric oxide regulate blood pressure in vivo? Biochem Biophys Res Commun 1989;160:881-6.

16. Whittle BJR, López-Belmonte J, Rees DD. Modulation of the vasodepressor actions of acetylcholine, bradykinin, substance $\mathrm{P}$ and endothelin in the rat by a specific inhibitor of nitric oxide formation. Br J Pharmacol 1989;98:646-52. 
17. White RP, Deane C, Vallance P, Markus HS. Nitric oxide synthase inhibition in humans reduces cerebral blood flow but not the hyperemic response to hypercapnia. Stroke 1998;29:467-72.

18. Calver A, Collier J, Moncada S, Vallance P. Effect of local intraarterial $\mathrm{N}^{\mathrm{G}}$-monomethyl-L-arginine in patients with hypertension: the nitric oxide dilator mechanism appears abnormal. J Hypertens 1992;10:1025-31.

19. Lefroy DC, Crake T, Uren NG, Davies GJ, Maseri A. Effect of inhibition of nitric oxide synthesis on epicardial coronary caliber and coronary flow in humans. Circulation 1993;88:43-54.

20. Joannides R, Richard V, Haefeli WE, Linder L, Lüscher TF, Thuillez C. Role of basal and stimulated release of nitric oxide in the regulation of radial artery caliber in humans. Hypertension 1995;26:327-31.

21. Misko TP, Moore WM, Kasten TP, Nickols GA, Corbett JA, Tilton RG, et al. Selective inhibition of the inducible nitric oxide synthase by aminoguanidine. Eur J Pharmacol 1993;233:119-25.

22. Corbett JA, Tilton RG, Chang K, Hasan KS, Ido Y, Wang JL, et al. Aminoguanidine, a novel inhibitor of nitric oxide formation, prevents diabetic vascular dysfunction. Diabetes 1992;41:552-6.

23. Hamilton CA, Williams R, Pathi V, Berg G, McArthur K, McPhaden AR, et al. Pharmacological characterisation of endothelium-dependent relaxation in human radial artery: comparison with internal thoracic artery. Cardiovasc Res 1999;42:214-23.

24. Taylor SG, Weston AH. Endothelium-derived hyperpolarising factor: a new endogenous inhibitor from the vascular endothelium. Trends Pharmacol Sci 1988;9:272-4.

25. Chen G, Suzuki H, Weston AH. Acetylcholine releases endothelium-derived hyperpolarizing factor and EDRF from rat blood vessels. Br J Pharmacol 1988;95:1165-74.

26. Furchgott RF, Vanhoutte PM. Endothelium-derived relaxing and contracting factors. FASEB J 1989;3:2007-18.

27. Buus NH, Simonsen U, Pilegaard HK, Mulvany MJ. Nitric oxide, prostanoid and non-NO, non-prostanoid involvement in acetylcholine relaxation of isolated human small arteries. $\mathrm{Br} \mathrm{J}$ Pharmacol 2000;129:184-92.

28. Nakashima M, Mombouli JV, Taylor AA, Vanhoutte PM. Endothelium-dependent hyperpolarization caused by bradykinin in human coronary arteries. J Clin Invest 1993;92:2867-71.
29. Vanhoutte PM. How to assess endothelial function in human blood vessels. J Hypertens 1999;17:1047-58.

30. MacAllister RJ, Fickling SA, Whitley GSJ, Vallance P. Metabolism of methylarginines by human vasculature: implications for the regulation of nitric oxide synthesis. Br J Pharmacol 1994;112:43-8.

31. MacAllister RJ, Rambausek MH, Vallance P, Williams D, Hoffmann K-H, Ritz E. Concentration of dimethyl-L-arginine in the plasma of patients with end-stage renal failure. Nephrol Dial Transplant 1996;11:2449-52.

32. Mendes Ribeiro AC, Roberts NB, Lane C, Yaqoob M, Ellory JC. Accumulation of the endogenous L-arginine analogue NGmonomethyl-L-arginine in human end-stage renal failure patients on regular haemodialysis. Exp Physiol 1996;81:475-81.

33. Horst M, Mehlhorn U, Hoerstrup SP, Suedkamp M, Rainer de Vivie E. Cardiac surgery in patients with end-stage renal disease: 10-year experience. Ann Thorac Surg 2000;69:96-101.

34. Boger RH, Bode-Boger SM, Szuba A, Tsao PS, Chan JR, Tangphao O, et al. Asymmetric dimethylarginine (ADMA): a novel risk factor for endothelial dysfunction. Its role in hypercholesterolemia. Circulation 1998;98:1842-7.

35. Quyyumi AA, Dakak N, Andrews NP, Gilligan DM, Panza JA, Cannon RO. Nitric oxide activity in the human coronary circulation: impact of risk factors for coronary atherosclerosis. J Clin Invest 1995;95:1747-55.

36. Radomski MW, Palmer RMJ, Moncada S. Comparative pharmacology of endothelium-derived relaxing factor, nitric oxide and prostacyclin in platelets. Br J Pharmacol 1987;92:181-7.

37. Adams MR, McCredie R, Jessup W, Robinson J, Sullivan D, Celermajer DS. Oral L-arginine improves endothelium-dependent dilatation and reduces monocyte adhesion to endothelial cells in young men with coronary artery disease. Atherosclerosis 1997;129:261-9.

38. Drexler H, Fischell TA, Pinto FJ, Chenzbraun A, Botas J, Cooke $\mathrm{JP}$, et al. Effect of L-arginine on coronary endothelial function in cardiac transplant recipients: relation to vessel wall morphology. Circulation 1994;89:1615-23.

39. Wallace AW, Ratcliffe MB, Galindez D, Kong JS. L-Arginine infusion dilates coronary vasculature in patients undergoing coronary bypass surgery. Anesthesiology 1999;90:1577-86.

\section{Timely}

The Journal of Thoracic and Cardiovascular Surgery delivers the information you need now. Articles usually appear within four months of acceptance. 